\title{
ANALISIS PENGARUH KUALITAS AUDIT DAN UKURAN PERUSAHAAN TERHADAP MANAJEMEN LABA
}

\begin{abstract}
The purpose of this research is to investigate and get empirical about auditor big four, auditor industry specialist, and size in the earning management limit by the firms audited for IPO firms. Earning management on this research is use discretionary accrual. Audit quality on this research is used by auditor big four and auditor industry specialist. Size on this research is measured by total assets.

The object of this research is non finance firms which do IPO (Initial Public Offerings) in Indonesia. It used 47 Indonesia IPO firms from 2008-2011. The method of data collection is purposive sampling method. Multiple regression is used to analysis data and develops the theory model.

The result of this research indicates that auditor big four proved cannot limit the earning management for firms which is audited by auditor big four when firms do IPO. Auditor ind ustry specialist can limit the earning management when firms do IPO in Indonesia. Size cannot limit the earning management when the firms do IPO in Indonesia.
\end{abstract}

Keywords: Auditor big four, Auditor Industry Specialist, Discretionary Accruals, Earning Management, Size.

\section{PENDAHULUAN}

Laporan keuangan merupakan sumber informasi yang digunakan untuk menilai posisi keuangan dan kinerja perusahaan yang terdiri dari neraca, laporan laba rugi, laporan perubahan ekuitas dan laporan arus kas (Standar Akuntansi Keuangan No. 1). Manajer dapat memodifikasi laporan keuangan yang disusun untuk menghasilkan jumlah laba (earning) yang diinginkan. Tujuan perusahaan membuat laporan keuangan salah satunya adalah sebagai indikator untuk menilai kinerja keuangan perusahaan. Jenis laporan keuangan yang mengukur keberhasilan operasi perusahaan untuk satu periode tertentu adalah laporan laba rugi (Widiatmaja, 2010).

Standar akuntansi yang ditetapkan oleh Ikatan Akuntansi Indonesia (IAI) mengijinkan pihak manajemen untuk mengambil suatu kebijakan dalam mengaplikasikan metode akuntansi yang akan digunakan untuk menyampaikan informasi mengenai kinerja perusahaan kepada pihakekstern. Manajer dapatmemilih kebijakan akuntansi yang dapat memaksimalkan expected utility atau nilai pasar perusahaan. Perilaku opportunistic dan kontrak efisien ini dapat mendorong manajer untuk melakukan manajemen laba.

Ritter,1991; Carter et al., 1998 menyebutkan bahwa manipulasi yang dikenal dengan istilah earnings management akan mengakibatkan penurunan kinerja (underperformance) setelah penawaran. Namun di sisi lain praktik earnings management dapat mempengaruhi nilai perusahaan (Mayangsari dan Wilopo,2002). Paek dan Press (1997) dalam Mayangsari dan Wilopo (2002) menyatakan bahwa nilai pasar perusahaan dipengaruhi oleh motivasi manajer yang mendasari adanya discretionary accruals dalam kebijakan earnings management.

Pemeriksaan terhadap laporan keuangan yang dilakukan oleh auditor memiliki kualitas yang berbedabeda. Oleh karena itu, Ardiati (2005) menyatakan bahwa auditing berkualitas tinggi (high-quality auditing) 
dapat bertindak sebagai pencegah manajemen laba yang efektif, karena reputasi manajemen akan hancur dan nilai perusahaan akan turun apabila pelaporan yang salah ini terdeteksi dan terungkap.

Penelitian yang dilakukan Zhou dan Elder (2003) dalam Ken Y. Chen, et al. (2005) menemukan bahwa KAP (Kantor Akuntan Publik) kelompok big five dan KAP spesialis industri sangat membatasi teknik manajemen laba bagi perusahaan yang melakukan IPO di AS. Berikutnya Ken Y. Chen et al. (2005) menemukan bahwa kelompok KAP big five memberikan peran yang lebih sedikit dalam manajemen laba pada saat perusahaan melakukan IPO di Taiwan serta KAP yang mempunyai kualitas lebih baik akan lebih bisa menekan teknik manajemen laba untuk perusahaan yang melakukan IPO di Taiwan

Kane dan Velury (2005) dalam Antonius (2007), mendefinisikan kualitas audit sebagai kapasitas dari auditor eksternal untuk mendeteksi adanya kesalahan material dan bentuk penyimpangan lainnya. Dengan adanya kualitas audit yang baik, maka diharapkan akan tercipta suatu pengendalian seperti preventive control, detective control dan reporting control dalam perusahaan. Kualitas audit yang baik sangat diperlukan oleh pemakai laporan keuangan tersebut dan akan digunakan sebagai dasar dalam membuat keputusan yang baik dan rasional.

Penelitian yang dilakukan oleh Craswell (1995) menyebutkan bahwa reputasi KAP kurang bernilai ketika dalam suatu industri juga terdapat KAP spesialis industri. KAP yang memiliki spesialisasi pada industri tertentu pasti akan memiliki pemahaman dan pengetahuan yang lebih baik mengenai kondisi lingkungan industri tersebut. Untuk industri yang memiliki teknologi akuntansi khusus, KAP spesialis akan memberikan jaminan kualitas audit yang lebih tinggi dan lebih baik dibandingkan KAP yang tidak spesialis. Namun hasil ini bertentangan dengan penelitian yang telah dilakukan oleh Luhgiatno (2008) memberikan bukti bahwa kualitas audit yang terdiri dari variabel KAP big four dan KAP spesialis industri, keduanya tidak berpengaruh secara signifikan terhadap praktik manajemen laba.

Variabel lain yang mempengaruhi manajemen laba yaitu ukuran perusahaan. Semakin besar ukuran perusahaan, maka akan semakin banyak estimasi dan penilaian yang perlu diterapkan untuk tiap jenis aktivitas perusahaan yang semakin banyak pula.

Hasil penelitian yang dilakukan oleh Sylvia Veronica dan Siddharta Utama (2006) ditemukan bahwa kepemilikan keluarga dan kepemilikan institusional berhubungan positif, ukuran perusahaan berhubungan negatif signifikan, ukuran KAP berhubungan negatif, proporsi dewan komisaris independen berpengaruh positif, dan keberadaan komite audit berpengaruh negatif, sedangkan debt berpengaruh positif signifikan dengan manajemen laba.

Penelitian ini merupakan replikasi dari penelitian yang dilakukan oleh Luhgiatno (2008) yang berjudul "Analisis Pengaruh Kualitas Audit terhadap Praktik Manajemen Laba (Studi pada Perusahaan yang Melakukan IPO di Indonesia)". Penulis tertarik meneliti penelitian ini karena masih ada beda hasil penelitian. Selain itu penelitian ini menambahkan variabel ukuran perusahaan yang diperoleh dari penelitian yang dilakukan Sylvia Veronica dan Siddharta Utama (2006), karena salah satu tolok ukur besar kecilnya perusahaan adalah ukuran perusahaan yang merupakan faktor penting dalam pembentukan manajemen laba.

Jurnal Akuntansi Indonesia

66 


\section{TELAAH LITERATUR DAN PENGEMBANGAN HIPOTESIS}

\section{Pengaruh KAP Big Four Terhadap Manajemen Laba}

Semakin besar ukuran KAP (KAP berasal dari kelompok big five) diharapkan akan menghasilkan kualitas audit yang lebih baik sehingga dapat menjadi pembatas yang penting bagi manajemen laba dalam proses IPO di AS (Zhou dan Elder, 2003 dalam Ken Y. Chen at al., 2005). Diharapkan bahwa perusahaan yang melakukan IPO di Indonesia yang menggunakan auditor dari kelompok KAP big four akan kurang terlibat dalam praktik manajemen laba disbanding perusahaan yang menyewa auditor di luar KAP big four (Sylvia Veronica dan Siddharta Utama, 2006).

H1 : KAP big four berpengaruh negatif terhadap praktik manajemen laba bagi perusahaan yang melakukan IPO di Indonesia.

\section{Pengaruh KAP Spesialis Industri Terhadap Manajemen Laba}

Semakin sering KAP spesialis industri menangani klien dengan industri yang sama, maka semakin KAP tersebut akan spesialis terhadap bidang industri yang ditanganinya dan akan semakin memahami risiko audit yang akan dihadapi. Sehingga diharapkan KAP spesialis industri mampu meminimalisir terjadinya praktik manajemen laba pada perusahaan yang melakukan IPO di Indonesia.

H2: KAP spesialis industri berpengaruh negatif terhadap praktik manajemen laba bagi perusahaan yang melakukan IPO di Indonesia.

\section{Pengaruh Ukuran Perusahaan Terhadap Manajemen Laba}

Perusahaan yang besar lebih diperhatikan oleh masyarakat sehingga mereka akan lebih berhati-hati dalam melakukan pelaporan keuangan, sehingga akan berdampak perusahaan tersebut melaporkan kondisinya lebih akurat (Marihot dan Doddy, 2007). Diharapkan ukuran perusahaan akan meminimalisir praktik manajemen laba.

H3: Ukuran perusahaan berpengaruh negatif terhadap praktik manajemen laba bagi perusahaan yang melakukan IPO di Indonesia.

\section{METODE PENELITIAN}

Data yang digunakan dalam penelitian ini adalah data sekunder yang diperoleh dari BEI (Bursa Efek Indonesia) untuk laporan keuangan publik perusahaan yang melakukan IPO. Populasi penelitian ini adalah perusahaan yang melakukan IPO di Indonesia. Teknik pengambilan sampel menggunakan purposive sampling method, dengan kriteria: Semua perusahaan non finance yang melakukan IPO di Indonesia antara tahun 2008 sampai dengan tahun 2011. Perusahaan mengeluarkan laporan keuangan tahunan yang lengkap pada saat melakukan IPO.

Variabel dependen dalam penelitian ini adalah manajemen laba, yaitu suatu kondisi dimana manajemen melakukan intervensi dalam proses penyusunan laporan keuangan bagi pihak eksternal sehingga meratakan, menaikkan, dan menurunkan pelaporan laba. Manajemen laba diukur menggunakan discretionary accruals 
(DAC) yang dihitung menggunakan model Jones yang dimodifikasi, karena model ini adalah model yang paling baik yang sama-sama digunakan untuk mengukur manajemen laba (Lobo dan Zhou, 2001 dalam Wedari, 2004).

Sedangkan Variabel independen dalam penelitian ini adalah KAP Big Four dan Spesialisasi industri KAP. Menurut Ansi Shannaz Farahnaz (2010), KAP big four adalah kelompok empat firma jasa professional dan akuntansi internasional terbesar, yang menangani mayoritas pekerjaan audit untuk perusahaan publik maupun perusahaan swasta. Menurut Natawidnyana (2008). Variabel ini merupakan variabel dummy, yaitu skala 1 untuk perusahaan yang diaudit oleh KAP big four dan skala 0 untuk perusahaan yang diaudit oleh KAP non big four Spesialisasi Industri KAP (AUDIT) menggambarkan keahlian dan pengalaman audit seorang auditor pada bidang industri tertentu. Variabel ini merupakan variabel dummy, yaitu skala 1 untuk perusahaan yang diaudit oleh KAP spesialis industri dan skala 0 untuk perusahaan yang diaudit oleh KAP non spesialis industri. Ukuran perusahaan adalah suatu skala dimana dapat diklasifikasikan besar kecilnya perusahaan menurut berbagai cara, antara lain: log total aktiva (Marihot dan Doddy, 2007).

Metode analisis data dalam penelitian ini menggunakan analisis regresi berganda. Uji asumsi klasik dalam penelitian ini mencakup normalitas, multikolinieritas, heteroskedastisitas dan autokorelasi, seperti yang disarankan oleh Gujarati (1999).

\section{HASIL DAN PEMBAHASAN}

Berdasarkan data yang diperoleh dari Indonesian Capital Market Directory (ICMD) selama periode 20082011 di BEl. Pemilihan sampel dilakukan dengan metode purposive sampling dengan kriteria yang telah ditetapkan pada bab metode penelitian. Berdasarkan pada metode pemilihan sampel yang telah ditetapkan, maka diperoleh sampel sebanyak 47 Perusahaan. Data yang telah diperoleh sebelum dilakukan uji regresi maka dilakukan pengujian asumsi klasik. Berdasarkan hasil pengujian asumsi klasik data penelitian ini telah memenuhi asumsi klasik. Berikut ini adalah hasil persamaan regresi yang dioleh dengan menggunakan SPSS versi 13. adalah sebagai berikut :

\section{Pengujian Hipotesis}

Nilai signifikansi 0,044 < 0,05 dapat disimpulkan bahwa variabel KAP big four berpengaruh negatif dan signifikan terhadap manajemen laba perusahaan IPO. Dengan demikian hipotesis pertama yang menyatakan bahwa KAP big four berpengaruh negatif terhadap manajemen laba IPO terbukti (H1 diterima). KAP big four berpengaruh negatif signifikan terhadap manajemen laba, hal ini mengindikasikan bahwa KAP big four memiliki tingkat kredibilitas yang tinggi di benak investor dan bagi perusahaan. Dengan akrual yang tinggi, perusahaan memiliki peluang yang lebih luas untuk melakukan manajemen laba yang opportunistik dan memiliki inisiatif untuk menyewa auditor dari kelompok big four. Hasil yang sama juga diungkapkan oleh Zhou dan Elder (2003) dalam Ken Y Chen at al (2005) yang membuktikan bahwa kualitas audit yang berasal dari kelompok big five menjadi pembatas yang penting menjadi manajemen laba dalam proses IPO di AS

Nilai signifikansi 0,756 >0,05 dapat disimpulkan bahwa variabel KAP spesialis industri berpengaruh 
positif tidak signifikan atau tidak berpengaruh terhadap manajemen laba perusahaan IPO. Dengan demikian hipotesis kedua yang menyatakan bahwa KAP spesialis industri berpengaruh negatif terhadap manajemen laba IPO tidak terbukti (H2 ditolak).

KAP Spesialis Industri tidak berpengaruh terhadap manajemen laba, kondisi ini terjadi karena setiap KAP memiliki pemahaman tentang industri perusahaan yang akan ditekuninya, apalagi sampel dalam penelitian ini adalah perusahaan manufaktur dimana tipe laporan keuangannya hampir sama, lain halnya dengan perbankan dan perusahaan keuangan lainnya. Hasil ini mendukung penelitian yang dilakukan oleh Luhgiatno (2008) yang membuktikan bahwa KAP spesialis industri tidak berpengaruh terhadap manajemen laba.

Nilai signifikansi 0,000 0,05 dapat disimpulkan bahwa variabel ukuran perusahaan berpengaruh negatif dan signifikan terhadap manajemen laba perusahaan IPO. Dengan demikian hipotesis ketiga yang menyatakan bahwa ukuran perusahaan berpengaruh negatif terhadap manajemen laba IPO terbukti (H3 diterima). Ukuran perusahaan berpengaruh negatif signifikan terhadap manajemen laba, hal ini terjadi karena perusahaan yang berukuran besar memiliki basis pemegang kepentingan yang lebih luas, sehingga berbagai kebijakan perusahaan besar akan berdampak lebih besar terhadap kepentingan publik dibandingkan dengan perusahaan kecil. Hasil ini mendukung penelitian Veronica dan Utama (2006) yang membuktikan bahwa ukuran perusahaan berpengaruh negative signifikan terhadap pengelolaan laba.

\section{SIMPULAN, KETERBATASAN DAN SARAN}

Berdasarkan hasil penelitian yang telah dilakukan, maka dapat dibuat kesimpulan sebagai berikut : pertama, KAP big four berpengaruh negatif signifikan terhadap manajemen laba, hal ini mengindikasikan bahwa KAP big four memiliki tingkat kredibilitas yang tinggi di benak investor dan bagi perusahaan dengan akrual yang tinggi memiliki peluang yang lebih luas untuk melakukan manajemen laba yang opportunistik dan memiliki inisiatif untuk menyewa auditor dari kelompok big four. Kedua, KAP spesialis industri tidak berpengaruh terhadap manajemen laba, kondisi ini terjadi karena setiap KAP memiliki pemahaman tentang industri perusahaan yang akan ditekuninya, apalagi sampel dalam penelitian ini adalah perusahaan manufkatur dimana tipe laporan keuangannya hampir sama, lain halnya dengan perbankan dan perusahaan keuangan lainnya. Ketiga, Ukuran perusahaan berpengaruh negatif signifikan terhadap manajemen laba, hal ini terjadi karena perusahaan yang berukuran besar memiliki basis pemegang kepentingan yang lebih luas, sehingga berbagai kebijakan perusahaan besar akan berdampak lebih besar terhadap kepentingan publik dibandingkan dengan perusahaan kecil.

Beberapa keterbatasan dalam penelitian ini yang masih perlu menjadi bahan revisi penelitian selanjutnya, yaitu mengenai pemilihan sampel. Sampel hanya menggunakan perusahaan yang melakukan IPO selama tahun 2008-2011, dengan sampel sebanyak 47 perusahaan. Penelitian ini hanya bisa menjelaskan manajemen laba sebesar 27,30 persen, dan belum menggunakan variabel rasio keuangan. 


\section{DAFTAR PUSTAKA}

Antonius Adolf Tandi. 2007. "Pengaruh Struktur Kepemilikan, Ukuran Perusahaan, Dan Hutang Terhadap Jasa Audit yang Berkualitas Pada Perusahaan Go Public di BEJ". Tesis Program Pasca Sarjana Magister Akuntansi Universitas Diponegoro (tidak dipublikasikam).

Ardiati, Aloysia Yanti. 2005. "Pengaruh Manajemen Laba terhadap Return Saham pada Perusahaan yang Diaudit oleh KAP Big 5 dan KAP Non Big 5". Jurnal Riset Akuntansi Indonesia Vol. 8, No. 3, hal. 235-249.

Carter, R.B., F.H. Dark., and A.K. Singh., 1998. "Underwriter Reputation, Initial Returns, and the Long-run Performance of IPO Stocks". The Journal of Finance. Vol LIII. No. 1 (Februari), Hal. 285-311.

Craswell, A., Francis, J., and Taylor, S., 1995. "Auditor Brand Name Reputations and Industry Specialization". Journal of Accounting and Economics. Vol. 20 No. 3, pp. 297-322.

Gujarati, D, 1999. Econometric, Singapore: McGraw Hill

Ken Y. Chen, Kuen-Lin Lin, dan Jian Zhou, 2005. "Audit Quality and Earnings Management for Taiwan IPO Firms". Manajerial Auditing Journal. Vol. 20 No. 1, pp. 86-104.

Luhgiatno, (2008), Analisis Pengaruh Kualitas Audit terhadap Menejemen Laba Studi Pada Perusahaan yang Melakukan IPO di Indonesia, Fokus Ekonomi. vol. 5 no. 2 (Des. 2010), halaman 15-31.

Marihot, Nasution dan Doddy Setiawan. 2007. "Pengaruh Corporate Governance Terhadap Manajemen Laba di Industri Perbankan Indonesia". Simposium Nasional Akuntansi 10. Makassar.

Mayangsari, Sekar. 2004. "Bukti Empiris Pengaruh Spesialisasi Industri Auditor Terhadap Earning Response Coefficient". Jurnal Riset Akuntansi Indonesia Vol 7 No 2, Mei.

Mayangsari, Sekar dan Wilopo, 2001. "Konservatisme Akuntansi, Value Relevance, dan Discretionary Accruals: Implikasi Empiris Model Feltham-OhIson 1996". Kumpulan Makalah SNA IV. Hal. 685-708.

Nuryaman. 2008. "Pengaruh Konsentrasi Kepemilikan, Ukuran Perusahaan, dan Mekanisme Corporate Governance terhadap Manajemen Laba". Simposium Nasional Akuntansi 11. Pontianak.

Scott, R.W., 2003. "Financial Accounting Theory, Third Edition". Toronto: Pearson Education Canada Inc.

Standar Akuntansi Keuangan (IAI), 2004. Salemba Empat. Jakarta.

Veronica N.P.S., dan Yunivi S. Bachtiar, 2003. "Hubungan antara Manajemen Laba dengan Tingkat Pengungkapan Laporan Keuangan". Makalah SNA VI: hal 328-349.

Veronica, Sylvia dan Yanivi S. Bachtiar. 2004. "Good Corporate Governance, Information Asymetry and Earnings Management". Simposium Nasional Akuntansi 7. Denpasar.

Veronica, Sylvia dan Siddharta Utama. 2006. “Pengaruh Struktur Kepemilikan, Ukuran Perusahaan, dan Praktek Corporate Governance Terhadap Pengelolaan Laba (Earnings Management)". Jurnal Riset Akuntansi Indonesia Vol. 9, No. 3, hal. 307-326.

Widyaningdyah, Agnes Utari. 2001. "Analisis Faktor-Faktor yang Berpengaruh Terhadap Earnings Management pada Perusahaan Go Public di Indonesia". Jurnal Akuntansi dan Keuangan Vol. 3, No. 2, hal. 89-101. 
Lampiran 1

Tabel 4.5

\section{Hasil Regresi}

\begin{tabular}{|c|c|c|c|c|c|c|}
\hline \multicolumn{7}{|c|}{ Coefficients $^{a}$} \\
\hline & & \multicolumn{2}{|c|}{ Unstandardized } & Standardized & & \\
\hline 1 & (Constant) & $-15,773$ & 3,552 & & $-4,441$ & ,000 \\
\hline & KAP big four & $-1,774$ & ,854 &,- 282 & $-2,078$ & ,044 \\
\hline & Spesialis industri & ,395 & 1,264 & ,041 & ,312 & ,756 \\
\hline & Ukuran perusahaan & 1,149 & ,259 &, 596 & 4,429 & ,000 \\
\hline
\end{tabular}

a. 